\title{
Inventory of Rubiaceae species in Mt. Pao Range, Ilocos Norte, Northwestern Luzon, Philippines
}

\author{
MAE ANN R. BATUYONG ${ }^{1,2, \vartheta}$, MICHAEL A. CALARAMO ${ }^{3}$, GRECEBIO JONATHAN D. ALEJANDRO ${ }^{1,4}$ \\ ${ }^{1}$ The Graduate School, University of Santo Tomas. España Blvd., 1015 Manila, Philippines, "email: mrbatuyong@mmsu.edu.ph \\ ${ }^{2}$ Department of Biological Sciences, College of Arts and Sciences, Mariano Marcos State University, City of Batac, 2906, Ilocos Norte, Philippines \\ ${ }^{3}$ Northwestern University Ecological Park \& Botanical Garden. Airport Avenue, Bengcag, Laoag City, 2900, Ilocos Norte, Philippines \\ ${ }^{4}$ Department of Biological Sciences, College of Science \& Research Center for the Natural and Applied Sciences, University of Santo Tomas. España \\ Boulevard, 1015 Manila, Philippines.
}

Manuscript received: 17 June 2021. Revision accepted: 31 July 2021.

\begin{abstract}
Batuyong MAR, Calaramo MA, Alejandro GJD. 2021. Inventory of Rubiaceae species in Mt. Pao Range, Ilocos Norte, Northwestern Luzon, Philippines. Biodiversitas 22: 3604-3612. Botanical assessments in the Philippines are mostly conducted on declared Protected Areas (PAs). However, many remaining potentially interesting and largely unexplored floristic sites are not considered PA, one of which is the Mt. Pao Range in the Municipality of Adams, located in Ilocos Norte, Philippines. Among the flowering plant family, Rubiaceae is one with the largest number of endemic species and genera in the Philippines Thus, floristic surveys of Rubiaceae species were conducted, and collections were made from September 2019 to March 2021. A total of 39 species belonging to 13 tribes and 24 genera of the family were recorded. These constitute $7.09 \%$ of the total Philippine Rubiaceae. Of these species, 18 are Philippine endemics while two are considered narrow endemic to Mt. Pao. Two endemic genera were also found in the area Antherostele and Kanapia. According to the Updated National List of Threatened Philippine Plants, their conservation status in the Department of Environment and Natural Resources (DENR) Administrative Order No. 2017-11 found one species assessed as Critically Endangered (Antherostele callophylla). This study contributes to the data on the distribution and occurrence of Philippine Rubiaceae. Moreover, it also highlights the area's importance with the presence of threatened and endemic species as an area of concern for protection and conservation.
\end{abstract}

Keywords: Conservation, inventory, Ilocos Norte, Mt. Pao, Rubiaceae

\section{INTRODUCTION}

Rubiaceae, widely known as the coffee family, ranks fourth among the angiosperm family and with more than 13,000 species of trees, shrubs, herbs, geofrutices, myrmecophiles, epiphytes, and lianas (Alejandro and Liede 2003; Alejandro 2007; Bremer and Eriksson 2009; Davis et al. 2009). They occupy a broad range of distribution and habitat worldwide, particularly in the subtropics and tropics. The family is notable and valued due to its economic importance in medicine, agriculture, pharmaceuticals and horticulture. Members of the family are easily recognized and distinguished in the field by the presence of simple, opposite or whorled, entire leaves, interpetiolar stipules, and an inferior ovary (Robbrecht 1988).

The Philippines is home to approximately 550 species in about 80 genera, accounting for $12.1 \%$ of the Rubiaceae worldwide (Alejandro and Liede 2003; Alejandro 2007), of which $83 \%$ are endemic (Davis et al. 2009). The following endemic genera are being considered, Antherostele Bremek., Greeniopsis Merr., Kanapia Arriola \& Alejandro and Villaria Rolfe, and (Alejandro and Liede 2003; Alejandro 2007; Alejandro et al. 2010, 2011; Arriola et al. 2016). Given these taxa, their confined distribution and geographic isolation suggest high value and importance in genetic diversity and biodiversity. And not only that, this suggests a more vulnerable and higher risk for loss (Ong et al. 2002; Rydin et al. 2008). Not surprisingly, in the global assessment of the family by Davis et al. (2009), the Philippines ranked tenth on the 20 most diverse regions for Rubiaceae and part of the top five highest areas which hold the most number of endemic species. It is likewise one among the main families in the Philippines contributing to the threatened plant list (Fernando et al. 2008). In the past decade, there is an emergence of taxonomic and phylogenetic papers focused on the Philippine Rubiaceae (e.g.) Uy and Alejandro 2012; Obico and Alejandro 2013; Banag and Alejandro 2014; Villanueva et al. 2016; Banag et al. 2017; Chavez et al. 2021; Ordas et al. 2021). In addition, the recollection and discovery of new species (Alejandro 2015; Arriola and Alejandro 2015; Salamanes et al. 2015; Alejandro and Meve 2016; Arriola et al. 2016; Ordas et al. 2017; Alfeche et al. 2020; Biag and Alejandro 2020; Batuyong et al. 2021b). Tantamount to these studies is an understanding of the distribution, ecology and biology of species within the family, in various ecosystems, which still remain largely limited and incomplete. The renowned work made by Merrill, "An Enumeration of Flowering Plants", which contributed to Philippine botany, is now outdated with almost a century old. Thus, there is an imminent need for recollections and new listings to be made for updated floristic studies. To date, some of the recently published documentation of Rubiaceae in the 
Philippines are in Northern Sierra Madre Natural Park (Biag and Alejandro 2021), two protected areas in Ilocos Norte (Batuyong et al. 2021) and in Eastern Samar, Visayas (Ordas et al. 2019). Alejandro (2007) emphasized that Rubiaceae are extremely diverse, and it is crucial that continuous fieldwork and taxonomic studies must be done.

Most of the botanical assessments in the Philippines were performed in declared Protected Areas (PAs). However, there are several unexplored areas that may be considered interesting for floristic studies but not considered as PAs, one of which is the Mt. Pao Range in the Municipality of Adams, Ilocos Norte, Philippines. Adams is within the northern tip part of the Cordillera Mountain Range of Ilocos Norte (Vallejo 2014), situated on mountainous terrain with only one barangay. It has a total land area of 15,931 ha, wherein two parcels of the land were included within the Kalbario Patapat Natural Park (KPNP), and the other one is declared as "Adams Critical Wildlife Habitats" (Department of Environment and Natural Resources DAO No. 2013-23), that has a heavily forested landscape classified as old-growth dipterocarp forest in the region along with the contiguous forest of adjoining mountainous interior towns. Other areas within the municipality are still relatively undisturbed, such as the Mt. Pao Range while few are partly disturbed by scattered residential communities and agricultural activities. Notably, some of the recently described species in the area include Amorphophallus adamsensis (Magtoto et al. 2013), Pyrostria triflora (Arriola et al. 2015), Nepenthes aenigma (Gronemeyer et al. 2016), and Begonia palemlemensis (Calaramo et al. 2019). Considering the scarcity of biological information on the flora of Mt. Pao Range, this paper presents the first local documentation of Rubiaceae species, which further contributes to the update on the knowledge of Philippine Rubiaceae. In addition, notes on their habit, ecology and current conservation status are also provided.

\section{MATERIALS AND METHODS}

\section{Study area}

Fieldwork was conducted in the municipality of Adams, covering the Mt. Pao Range (Figure 1). Mount Pao Range is one of the lowland tropical rainforests among the municipality's mountainous terrain (Figure 2.). It has an estimated total land area of 5796.39 ha with an elevation of 500 meters masl up to approximately $680 \mathrm{~m}$ asl. The area is predominantly mountainous, has a slope of above $50 \%$ mountain while areas of the foot slopes are rolling to hilly with $18-30 \%$ slope. Generally, the climate in the Ilocos Norte province is classified as Type I, described to have two pronounced seasons: dry from November to April and wet during the rest of the year. However, Adams is located in the eastern part of the province and is influenced by the prevailing climate of the Cordilleras, classified as Type III according to the Modified Corona Climate Classification. Under this climate type, seasons are not very pronounced. It is relatively dry from March to June, and the wet season begins in July and ends in October.

\section{Data collection}

Before the field activity in the area, certification from the Local Government Unit (LGU) of Adams and free prior informed consent from the tribal leader in the area was secured and submitted to DENR Office-Region 1.

Field surveys were done in September 2019, February 2020, and March 2021. Purposive sampling was employed in the study. Plant specimens showing the characteristics of Rubiaceae were collected along the entirety of the trail and $10 \mathrm{~m}$ outside the trail. Then, triplicates of each representative specimen were collected, pressed, dried, and mounted following standard procedures for herbarium vouchers. The specimens were initially identified in the field, while unidentified specimens were taken back to the herbarium of Northwestern Luzon for further identification. In addition, field photo documentation was utilized and referred to online databases such as JSTOR Plants (https://plants.jstor.org; 2000 onwards), Co's Digital Flora of the Philippines (https://www.phytoimages.siu.edu; Pelser et al. 2011 onwards), and the POWO 2021 (http://www.plantsoftheworldonline.org).

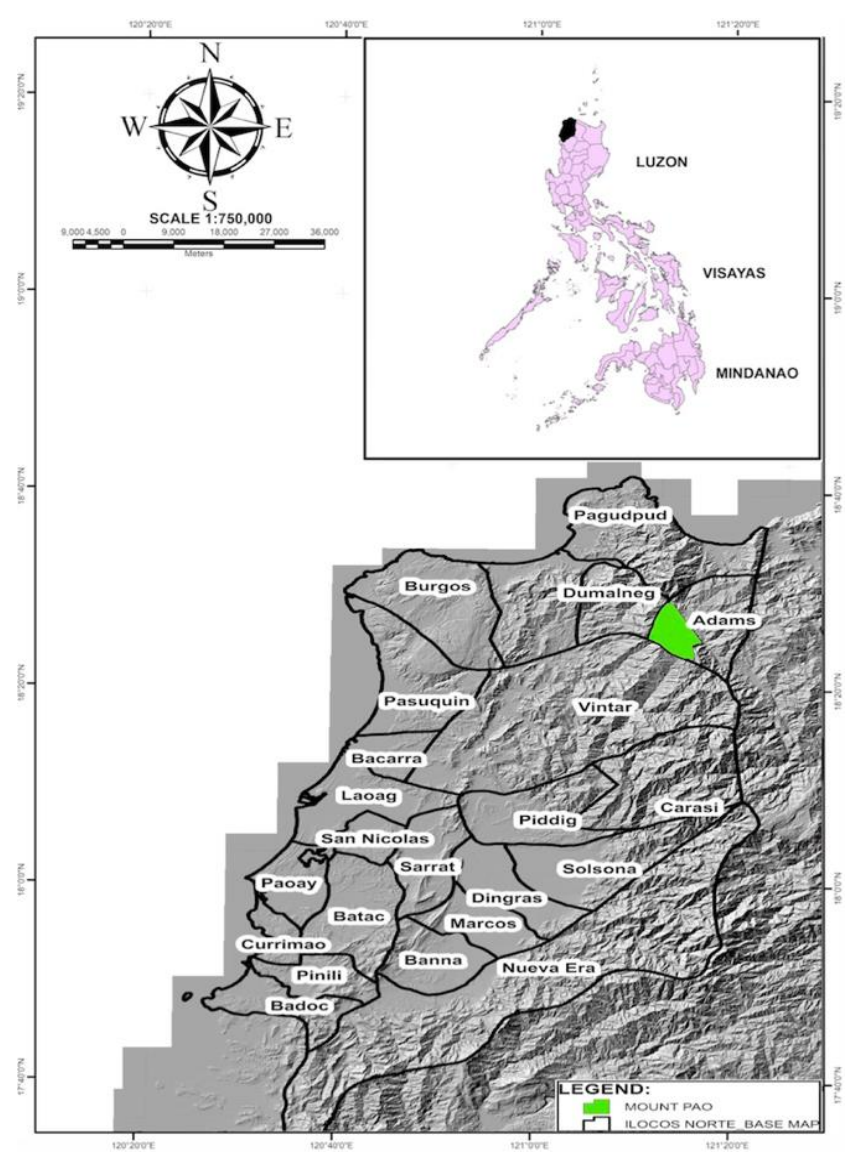

Figure 1. Location of the study area in Ilocos Norte, Northwestern Luzon, Philippines. Area surveyed is marked in green color. 

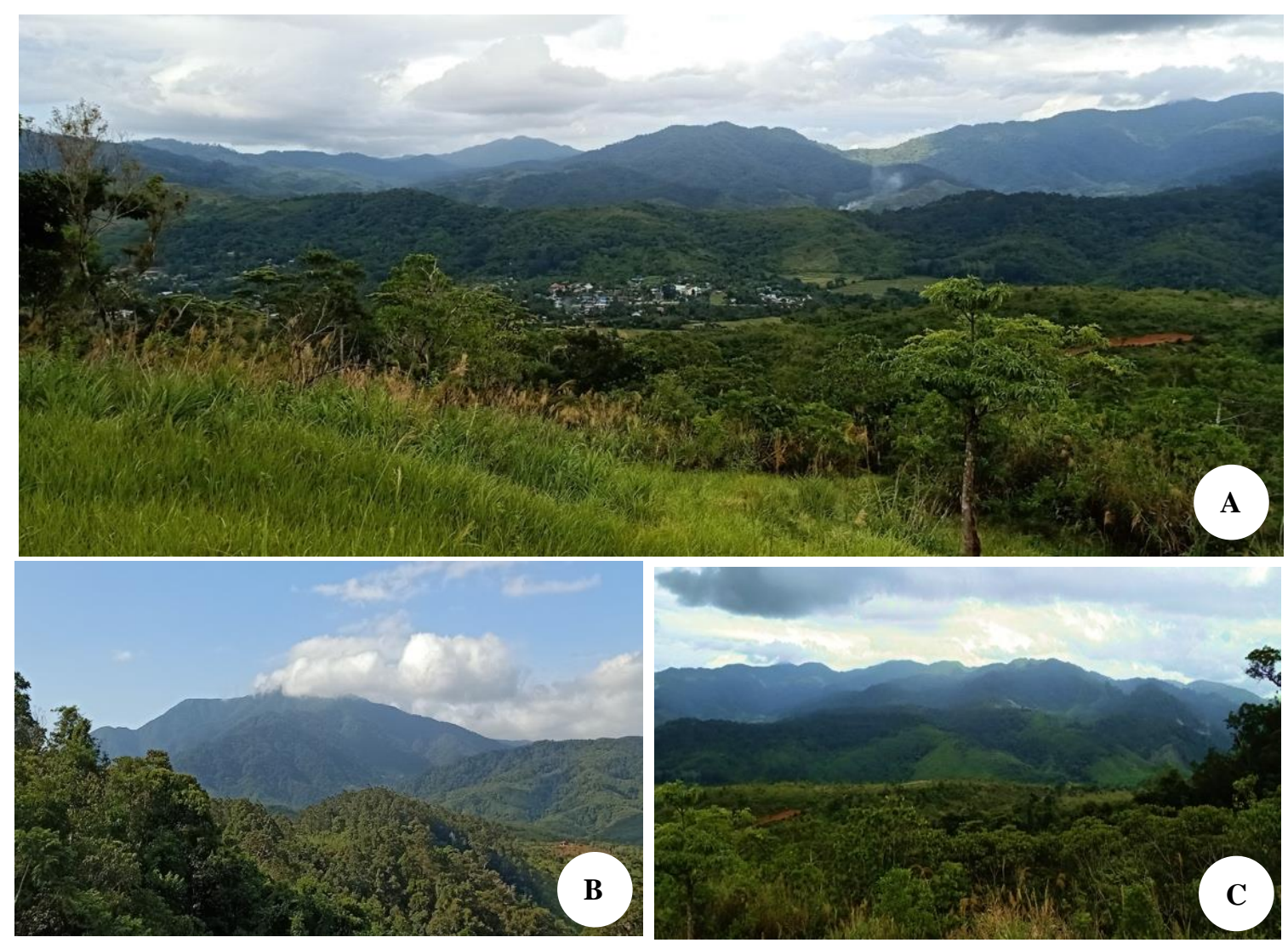

Figure 2. The study site in Ilocos Norte, Northwestern Luzon, Philippines. A. View of the mountainous terrain surrounding the Municipality of Adams; B. Part of Mt. Pao Range with Mt. Palemlem at the background; C. View portion of Mt. Pao Range.

Collections from the following local herbaria Herbarium of Northwestern Luzon (HNUL), Philippine National Herbarium (PNH), and University of Santo Tomas Herbarium (USTH) were also examined and compared to the collected specimens to facilitate the identification. Consequently, the living collections found at the Northwestern University Ecological and Botanical Garden (NUEBG) were also utilized as cross-references for the collections. Voucher specimens were deposited at HNUL. The specimens' accepted botanical names, correct spelling, and synonymy were further verified using Co's Digital Flora of the Philippines (Pelser et al. 2011 onwards), and World Checklist of Selected Plant Families (https://wcsp.science.kew.org/cite.do; WCSP 2021). The Arc-GIS v.10.5 was utilized for the preparation of the map.

The collected plants were checked for their occurrence, distribution, and endemicity in the Co's Digital Flora of the Philippines (Pelser et al. 2011 onwards) and Global Biodiversity Information Facility (http://www.gbif.org/; GBIF 1999).

Further, the classification of the conservation status of each species is indicated and taken from the red list of threatened species by the IUCN and the updated national list of threatened plants in the Philippines (DENR AO 2017-11).

\section{RESULTS AND DISCUSSION}

\section{Composition of Rubiaceae species in Mt. Pao Range}

The present study revealed 39 species belonging to 13 tribes and 24 genera (Table 1). These constitute $7.09 \%$ of the total Philippine Rubiaceae. From the various tribes documented, the highest number of species was recorded by Psychotrieae (six species) followed by Naucleeae, Spermacoceae (five species each), Ixoreae, Lasianthaceae, and Urophylleae (four species each). The tribes Ophiorrhizeae and Vanguerieae were represented by three species while the tribes Argostemmateae, Augusteae, Guettardeae, Morindeae and Mussaendea were represented by one species each. Most of the recorded and identified species were trees $(35.90 \%)$, followed by shrubs $(30.77 \%)$, herbs $(20.51 \%)$, lianas $(7.69 \%)$ and epiphytes $(5.13 \%)$, as depicted in Figure 3.A.

Species distribution in terms of endemicity listed 17 species as endemic $(51.52 \%)$ while the rest of the identified species are also distributed in other countries $(48.48 \%)$ (Figure 3.B), which are assumed to have been introduced or naturalized in the Philippines (CDFP; Pelser et al. 2011 onwards). In addition, it is also worth mentioning that despite the low number of endemic species, two Philippine endemic genera are recorded in the area Antherostele and Kanapia. 
Table 1. List of Rubiaceae species identified in the study site, Ilocos Norte, Northwestern Luzon, Philippines

\begin{tabular}{|c|c|c|c|c|}
\hline Species & Habit & Endemicity & $\begin{array}{c}\text { Conservation } \\
\text { status }\end{array}$ & Accession number \\
\hline \multicolumn{5}{|l|}{ Tribe Argostemmateae } \\
\hline Mycetia javanica (Blume) Reinw. ex Korth. & $\operatorname{Tr}$ & $\mathrm{NE}$ & NE & HNUL 0018580 \\
\hline \multicolumn{5}{|l|}{ Tribe Agusteae } \\
\hline Wendlandia luzoniensis DC. (Figure 4.B) & $\operatorname{Tr}$ & NE & NE & HNUL 0018579 \\
\hline \multicolumn{5}{|l|}{ Tribe Guettardeae } \\
\hline Timonius ternifolius (Bartl. ex DC.) Fern. Vill. (Figure 5.A) & $\operatorname{Tr}$ & $\mathrm{E}$ & $\mathrm{NE}$ & HNUL 0018585 \\
\hline \multicolumn{5}{|l|}{ Tribe Ixoreaea } \\
\hline Ixora bibracteata Elmer (Figure 6.A) & Sh & $\mathrm{E}$ & $\mathrm{NE}$ & HNUL 0018581 \\
\hline Ixora cumingiana S.Vidal & $\mathrm{Sh}$ & $\mathrm{E}$ & $\mathrm{NE}$ & HNUL 0018582 \\
\hline Ixora luzoniensis Merr. (Figure 6.B) & $\mathrm{Sh}$ & $\mathrm{E}$ & NE & HNUL 0018583 \\
\hline Ixora macrophylla Bartl. ex DC. (Figure 4.C) & $\operatorname{Tr}$ & $\mathrm{NE}$ & NE & HNUL 0018584 \\
\hline \multicolumn{5}{|l|}{ Tribe Lasiantheae } \\
\hline Lasianthus sp. (Figure 4.D) & $\mathrm{Sh}$ & NE & NE & HNUL 0018616 \\
\hline Lasianthus attenuatus Jack (Figure 4.A) & $\mathrm{Sh}$ & NE & NE & HNUL 0018592 \\
\hline Lasianthus biflorus (Blume) M.Gangop. \& Chakrab. (Figure 4.E) & $\mathrm{Sh}$ & NE & NE & HNUL 0018613 \\
\hline Lasianthus hirsutus (Roxb.) Merr. & $\mathrm{Sh}$ & NE & $\mathrm{NE}$ & HNUL 0018593 \\
\hline \multicolumn{5}{|l|}{ Tribe Morindeae } \\
\hline Prismatomeris brachypus Ridl. & $\mathrm{Sh}$ & $\mathrm{E}$ & NE & HNUL 0018594 \\
\hline \multicolumn{5}{|l|}{ Tribe Mussaendeae } \\
\hline Mussaenda benguetensis Elmer (Figure 6.E) & $\operatorname{Tr}$ & $\mathrm{E}$ & $\mathrm{NE}$ & HNUL 0018586 \\
\hline \multicolumn{5}{|l|}{ Tribe Naucleeae } \\
\hline Mitragyna sp. (Figure 4.F) & $\operatorname{Tr}$ & & & HNUL 0018618 \\
\hline Neonauclea bartlingii var. cumingiana (S. Vidal) Ridsdale & $\operatorname{Tr}$ & $\mathrm{E}$ & $\mathrm{LC}$ & HNUL 0018587 \\
\hline Neonauclea reticulata (Havil.) Merr. & $\operatorname{Tr}$ & $\mathrm{NE}$ & NE & HNUL 0018597 \\
\hline Uncaria lanosa Wall & $\mathrm{Li}$ & NE & NE & HNUL 0018595 \\
\hline Uncaria perrottetii (A.Rich.) Merr. & $\mathrm{Li}$ & $\mathrm{E}$ & NE & HNUL 0018596 \\
\hline \multicolumn{5}{|l|}{ Tribe Ophiorrhizeae } \\
\hline Ophiorrhiza argostemmoides Elmer (Figure 6.C) & $\mathrm{He}$ & $\mathrm{E}$ & $\mathrm{NE}$ & HNUL 0018588 \\
\hline Ophiorrhiza oblongifolia DC. & $\mathrm{He}$ & $\mathrm{E}$ & NE & HNUL 0018590 \\
\hline Ophiorrhiza oblongilimba Merr. & $\mathrm{He}$ & $\mathrm{E}$ & $\mathrm{NE}$ & HNUL 0018589 \\
\hline \multicolumn{5}{|l|}{ Tribe Psychotrieae } \\
\hline Hydnophytum formicarum Jack (Figure 5.C) & Ep & $\mathrm{NE}$ & $\mathrm{NE}$ & HNUL 0018598 \\
\hline Myrmecodia tuberosa Jack (Figure 5.D) & Ep & $\mathrm{NE}$ & $\mathrm{NE}$ & HNUL 0018599 \\
\hline Psychotria sp. & $\mathrm{Sh}$ & & & HNUL 0018600 \\
\hline Psychotria ixoroides Bartl. ex DC. & $\mathrm{Li}$ & $\mathrm{E}$ & $\mathrm{NE}$ & HNUL 0018601 \\
\hline Psychotria manillensis Bartl. ex DC. & $\mathrm{Sh}$ & NE & NE & HNUL 0018602 \\
\hline Psychotria subsessiliflora var. subsessiliflora & $\operatorname{Tr}$ & $\mathrm{E}$ & NE & HNUL 0018614 \\
\hline \multicolumn{5}{|l|}{ Tribe Spermacoceae } \\
\hline Exallage cristata (Willd.) Nandikar \& K.C.Kishor (Figure 5.B) & $\mathrm{He}$ & NE & NE & HNUL 0018603 \\
\hline Hedyotis sp. & $\mathrm{He}$ & & & HNUL 0018604 \\
\hline Oldenlandia corymbosa $\mathrm{L}$. & $\mathrm{He}$ & $\mathrm{NE}$ & $\mathrm{NE}$ & HNUL 0018605 \\
\hline Spermacoce ocymoides Burm.f & $\mathrm{He}$ & $\mathrm{NE}$ & NE & HNUL 0018606 \\
\hline Spermacoce remota Lam. (Figure 5.E) & $\mathrm{He}$ & $\mathrm{NE}$ & NE & HNUL 0018607 \\
\hline \multicolumn{5}{|l|}{ Tribe Urophylleae } \\
\hline Antherostele callophylla Bremek (Figure 6.F) & $\operatorname{Tr}$ & $\mathrm{E}$ & $* \mathrm{CR}$ & HNUL 0018608 \\
\hline Praravinia sp. & $\operatorname{Tr}$ & & NE & HNUL 0018609 \\
\hline Urophyllum sp. & $\operatorname{Tr}$ & & $\mathrm{NE}$ & HNUL 0018610 \\
\hline Urophyllum caudatum Merr. & Sh & $\mathrm{E}$ & NE & HNUL 0018611 \\
\hline \multicolumn{5}{|l|}{ Tribe Vanguerieae } \\
\hline Kanapia monstrossa (A. Rich.) Arriola \& Alejandro & $\operatorname{Tr}$ & $\mathrm{E}$ & $\mathrm{NE}$ & HNUL 0018612 \\
\hline Psydrax sp. & $\operatorname{Tr}$ & & $\mathrm{NE}$ & HNUL 0018613 \\
\hline Pyrostria triflora Arriola, Calaramo \& Alejandro & Sh & $\mathrm{E}$ & $\mathrm{NE}$ & HNUL 0018615 \\
\hline
\end{tabular}




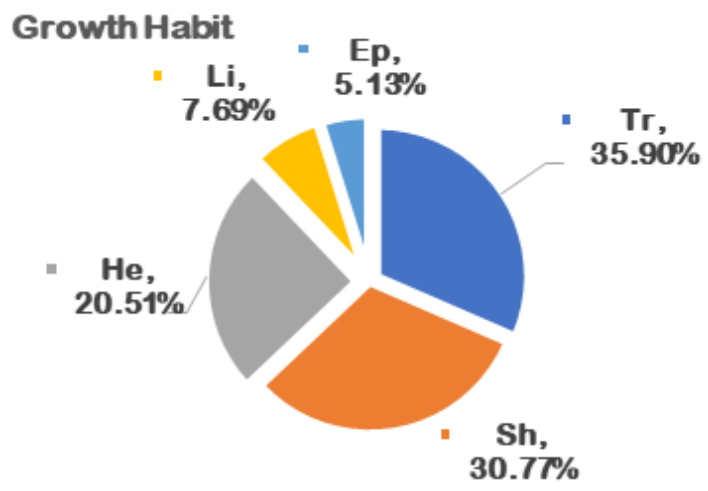

A

\section{Endemicity}

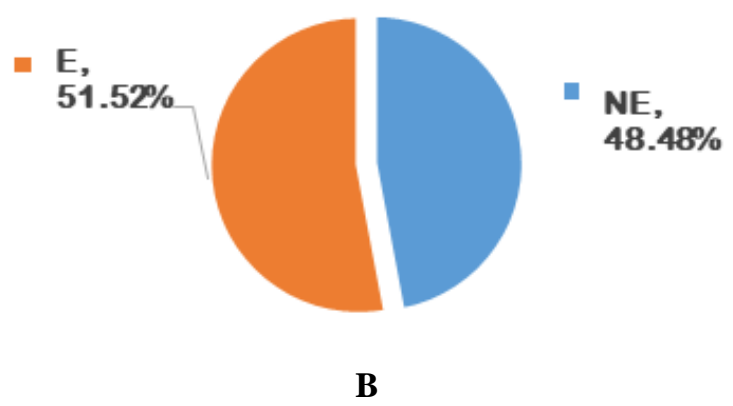

Figure 3. The number of collected Rubiaceae species in Mt. Pao Range, Ilocos Norte, Northwestern Luzon, Philippines. A. The number of species per growth habit. Note: Tr: trees, Sh: shrubs, He: herbs, Li: Lianas, Ep: epiphytes); B. Proportion of collected endemic and non-endemic species

While most of the species identified from the site were not assessed for their conservation status based on the international lists of threatened species (IUCN), the national list of threatened species (DENR Administrative Order 2017; CDFP; Pelser et al. 2011 onwards) revealed one species as Critically Endangered (CR), namely Antherostele callophylla Bremek.

During the field survey, some of the frequently encountered species were Ixora bibracteata Elmer, Lasianthus attenuatus Jack (Figure 4.A), Lasianthus hirsutus (Roxb.) Merr., Neonauclea bartlingii var. cumingiana (S. Vidal) Ridsdale, Neonauclea reticulata (Havil.) Merr. and Wendlandia luzoniensis DC (Figure 4.B). While other species were found to have fewer to single mature individuals in the surveyed site, such as Ixora macrophylla Bartl. ex DC (Figure 4.C), Kanapia monstrossa (A. Rich.) Arriola \& Alejandro, Lasianthus sp. (Figure 4.D), Lasianthus biflorus (Blume) M.Gangop. \& Chakrab. (Figure 4.E), Mitragyna sp. (Figure 4.F), Psychotria subsessiliflora var. subsessiliflora, Pyrostria triflora Arriola, Calaramo \& Alejandro and Timonius ternifolius (Bartl. ex DC.) Fern. Vill. (Figure 5.A). Sparsely distributed also with few immature individuals is A. callophylla. Noteworthy, this species is recorded to occur outside its type locality. On the other hand, a small population of Exallage cristata (Willd.) Nandikar \& K.C.Kishor (Figure 5.B), Hydnophytum formicarum Jack (Figure 5.C), Myrmecodia tuberosa Jack (Figure 5.D), and Ophiorrhiza argostemmoides Elmer were observed to occur in a single location. Davis et al. (2009) mentioned that Rubiaceae species are sensitive to disturbance in tropical regions.

Consequently, compared with other areas surveyed in the country, 29 species are similar from the previously reported by Batuyong et al. (2021) in Kalbario Patapat Natural Park (KPNP). This protected area is also located on the mountains of the Municipalities of Pagudpud and Adams and is described as one of the remaining remnants of an old-growth mix dipterocarp forest on the northwestern portion of Luzon along with Mt. Pao Range that is contiguous to Cagayan and Cordillera (DENR 2018). Whereas, nine species are also recorded comparable in Northern Sierra Madre Natural Park (NSMNP) covering Isabela (Biag \& Alejandro 2021), which holds the record of being the widest remaining tropical rainforest in the Island of Luzon (DENR-NSMNP Profile 2017). Lastly, seven species in Eastern Samar, Visayas (Ordas et al. 2019), where the vegetative area comprises mostly old-growth forests and includes diverse habitats ranging from mangrove lowland evergreen rainforests and limestone and ultramafic soil forests. Among the species commonly noted in these four areas are Spermacocea remota Lam. (Figure 5.E) and Uncaria lanosa Wall. Delprete and Jardim (2012) described that the family could be found at all strata of tropical vegetation and habitats at various habits, which considers this family one of the most significant components in tropical vegetation. Considerably, the family has been recorded and identified as one of the wellrepresented family documented in various diversity and floristic studies conducted in different forests ecosystem in the Philippines (Fernando et al. 2008; Amoroso et al. 2009; Aribal and Fernando 2014; de Guzman et al. 2014; Malabrigo et al. 2018; Aureo et al. 2020).

\section{Notes on selected Philippine endemic taxa}

Among the tribes, the Ixoreaea and Ophiorrhizeae displayed the most number of endemic species, as shown in Table 1. Four species from the genus Ixora L. under the tribe Ixoreaea were collected, three of which are endemic, I. bibracteata Elmer (Figure 6.A), I. cumingiana S. Vidal and I. luzoniensis Merr (Figure 6.B). In the Philippines, out of the 34 species present, 25 are considered endemic (Banag et al. 2015, 2017). The I. bibracteata are found along the trail and forest ridges at a medium elevation from ca. 350-500 masl. Flowering and fruiting were observed from February to May. The other two endemic species, $I$. cumingiana and I. luzoniensis, are widely distributed in most islands and provinces in the Philippines (Pelser et al. 2011). The I. cumingiana was found at low to medium elevation ca. 250-450 m. It was observed flowering and fruiting when collected in February. At the same time, several individuals of I. luzoniensis were encountered and collected at an elevation of 360 masl near a river. 


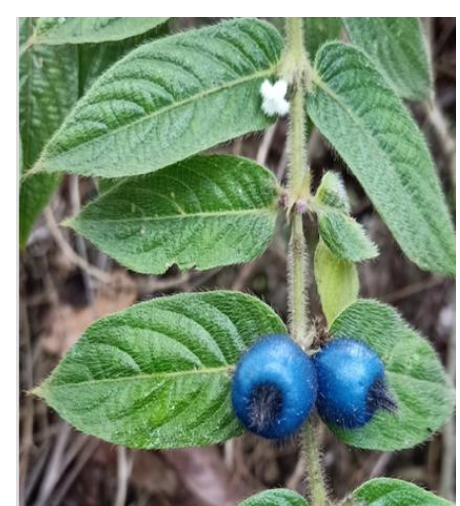

A

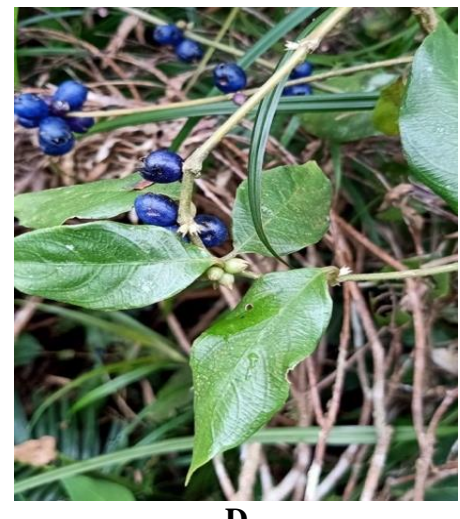

D

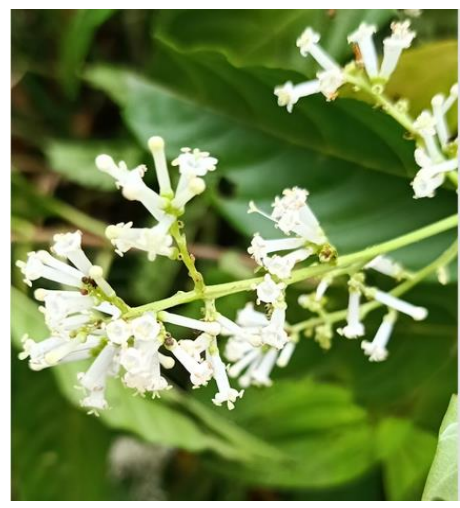

B

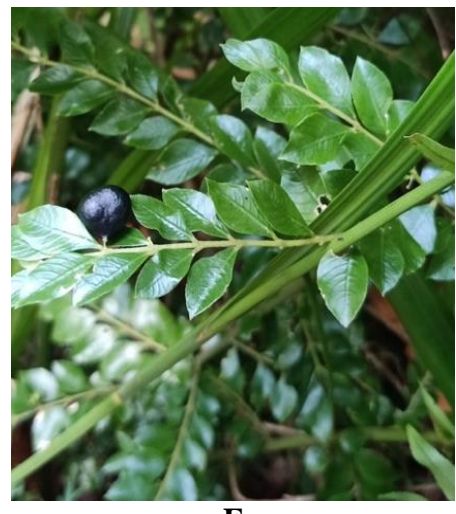

$\mathbf{E}$

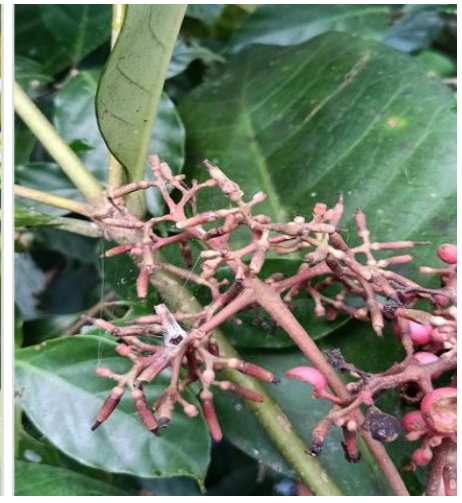

C

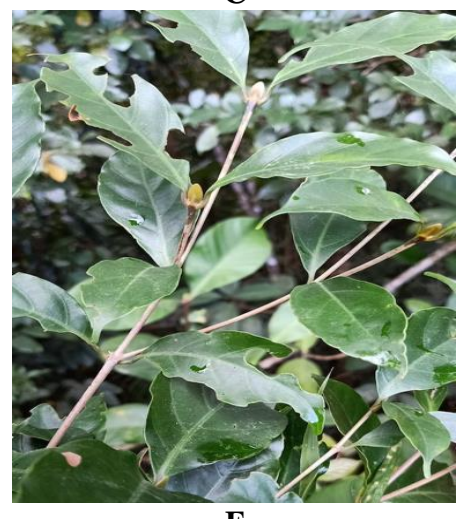

F

Figure 4. Representatives of Rubiaceae collected in Mt. Pao, Philippines. A. Lasianthus attenuatus, B. Wendlandia luzoniensis, C. Ixora macrophylla, D. Lasianthus sp., E. Lasianthus biflorus, F. Mitragyna sp. Photos taken by MA Batuyong and MA Calaramo

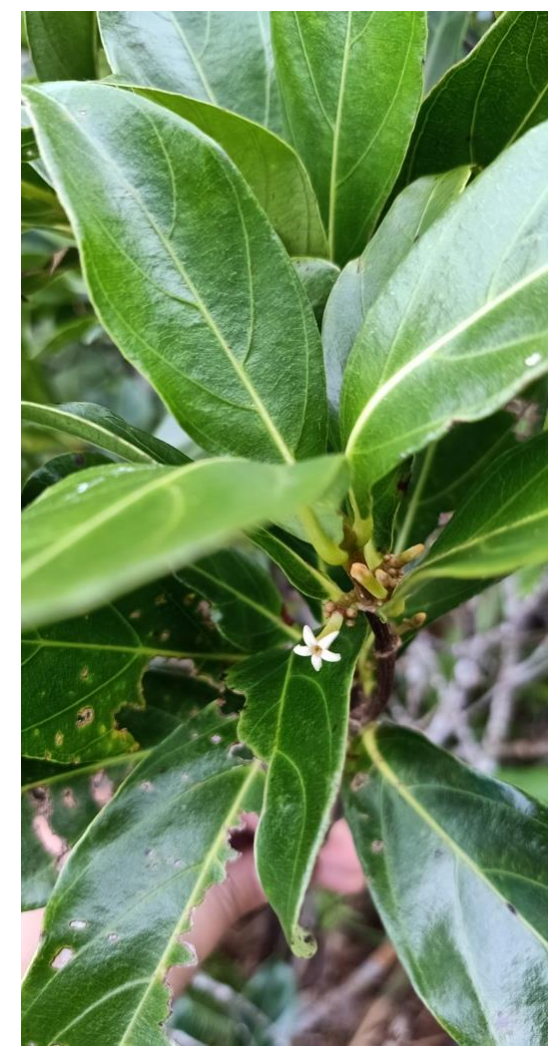

A

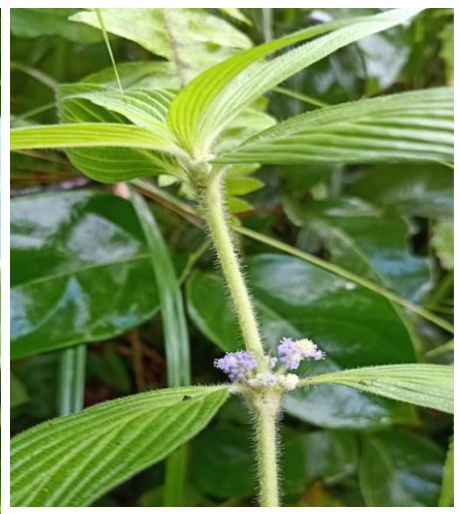

B

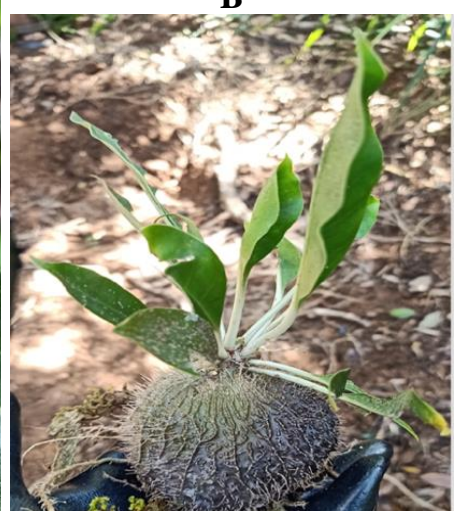

D

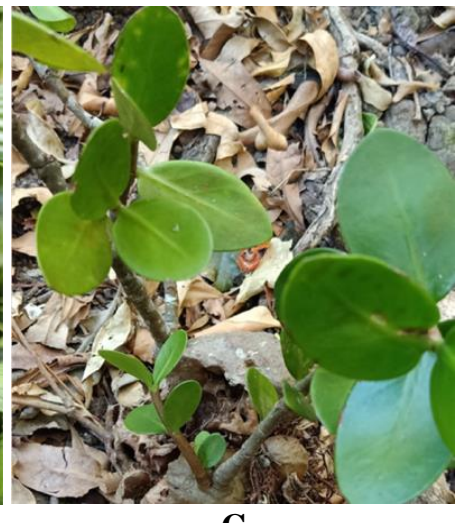

C

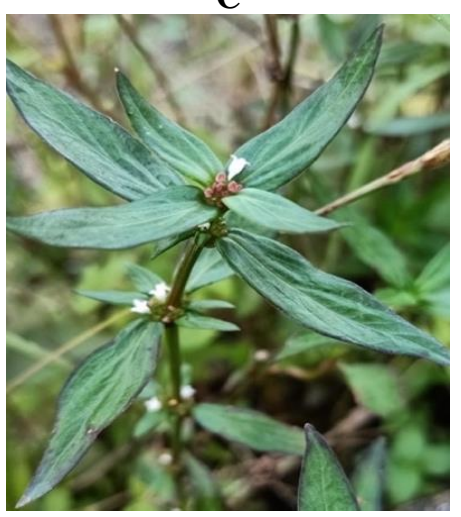

$\mathbf{E}$

Figure 5. Representatives of Rubiaceae collected in Mt. Pao, Philippines. A. Timonius ternifolius, B. Exallage cristata, C. Hydnophytum formicarum, D. Myrmecodia tuberosa, E. Spermacoce remota. Photos taken by MA Batuyong and MA Calaramo 


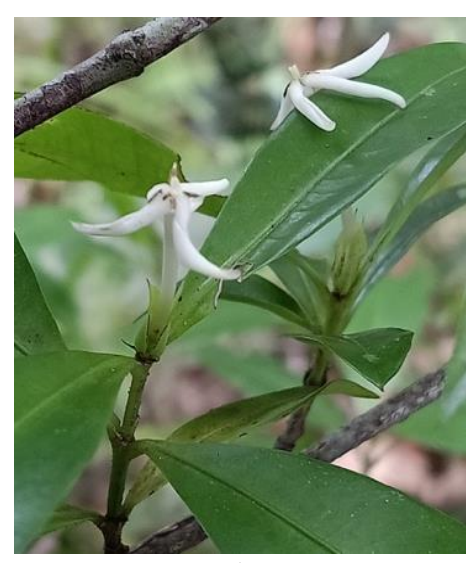

A

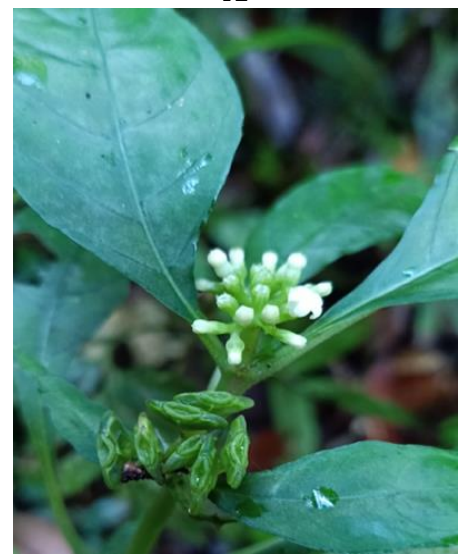

D

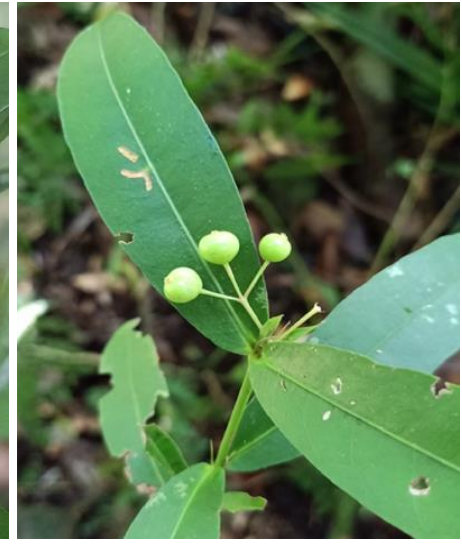

B

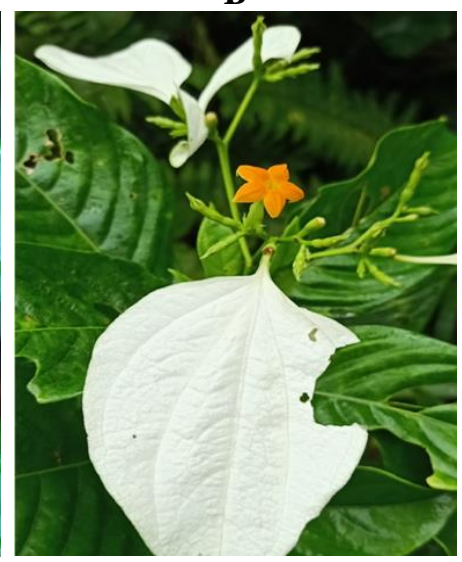

$\mathbf{E}$

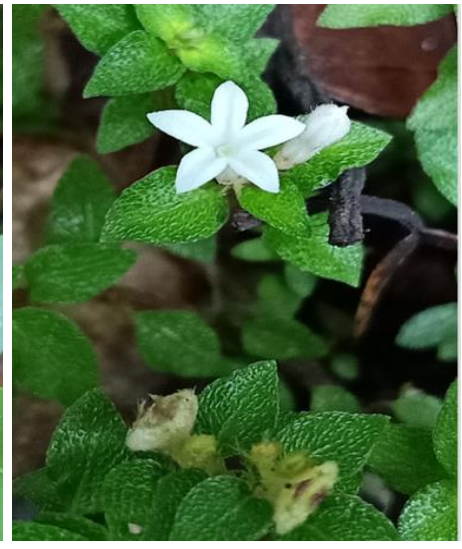

C

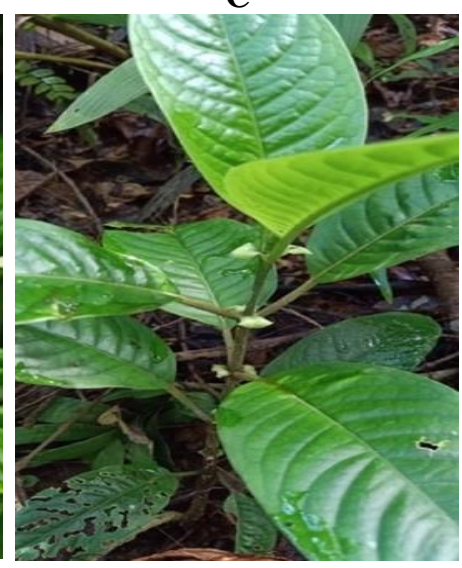

$\mathbf{F}$

Figure 6. Representatives of Rubiaceae collected in Mt. Pao, Ilocos Norte, Northwestern Luzon, Philippines. A. Ixora bibracteata, B. I. luzoniensis, C. Ophiorrhiza argostemmoides, D. O. oblongifolia, E. Mussaenda benguetensis, F. Antherostele callophylla. Photos taken by MA Batuyong and MA Calaramo

Merrill's (1923) and Alejandro (2007), they enumerated 17 endemic Philippine Ophiorrhiza species out of the 18 occurring species. In the updates of Philippine flora, Pelser et al. (2011 onwards) recorded the presence of 30 Ophiorrhiza species, wherein 28 are considered endemic. O. argostemmoides Elmer (Figure 6.C), O. oblongifolia DC, identified three species in the area. (Figure 6.D) and O. oblongilimba Merr.

Ophiorrhiza argostemmoides occurs along streams. It was previously observed only in Mindanao, however, the finding of this species represents additional record for the locality.

One representative species from the tribe Mussaendeae was likewise recorded, the Mussaenda benguetensis Elmer (Figure 6.E). It has been observed flowering and fruiting during the collection along the trail at an elevation ranging from 200 to 250 masl.

The Psychotria ixoroides Bartl. ex DC. exists as a lianescent shrub, its stipules are valvate to ovate and measure 2-6 mm long, glabrous. The leaf blades appear narrowly to broadly elliptic, oblanceolate to narrowly lanceolate, and measures 4-9 x 1.3-3.5 cm, base cuneate, apex acute to acuminate. The fruits are obovoid, $4-5 \mathrm{~mm}$ long, ribbed, white, pyrenes ribbed on outer surface. Only the fruits were seen during the collection in October.
Other endemic species such as A. callophylla (Figure 6.I) and Psychotria subsessiliflora var. subsessiliflora (Figure 6.F), were collected in the undisturbed area. However, we could expect potential degradation in the forest in the near future due to human encroachment. As observed during the fieldwork, the increasing population, developing tourism, agricultural activities such as slash and burn, and potential forest conversions all pose a threat to the flora and the entire biodiversity. In addition, the town of Adams is a budding destination for nature enthusiasts and adventurers, certainly because of the pristine environment. Therefore, these threats emphasize the need to effectively manage the area.

In conclusion, we initially documented 39 species belonging to 24 genera representing 13 tribes. This number of species comprises about $7.09 \%$ of the total number of Rubiaceae species in the Philippines. Seventeen (17) species are Philippine endemics, and two species are endemic to the province. As regards conservation, one is listed as Critically Endangered (DENR AO 2017-11). While this present study does not account for all species within Mt. Pao Range, the results provide a useful basis and increase the floristic data to build future evidencebased for effective conservation and protection of the area. As available and baseline information is essential to assist 
in implementing programs, policy formulation, and determination of areas that will become priorities for conservation, optimistically, the inclusion of the area in the future as an area of priority. As emphasized by Gordon et al. 2005, the six criteria relating to biodiversity value, such as the number of endemic species, diversity, conservation status, variety of taxa, are taken into consideration in selecting priority areas for conservation. Lastly, future studies should also consider and continue on the inventory of other plants, such as bryophytes as well as plant associations and environment interactions.

\section{ACKNOWLEDGEMENTS}

The authors acknowledge the Department of Environment and Natural Resources Region 1, Provincial Environment and Natural Resources Office of Ilocos Norte, and CENRO-Northern Ilocos Norte, LGU-Adams, and the community of Yapayao tribe for the endorsement and consent allowing us to perform the study. Grateful appreciation is also given to the directors and curators of CAHUP, HNUL, PNH, and USTH for granting access to the herbarium collections. In addition, acknowledgment is due to Joey Nazareno and Forester Joseph Leweilyn Acang for providing the map. Lastly, the first author is thankful to the Commission of Higher Education (CHED) and Mariano Marcos State University (MMSU) for the scholarship grants.

\section{REFERENCES}

Alejandro GJD, Liede S. 2003. The Philippine Rubiaceae genera. Updated synopsis in INTKEY databases of the DELTA system. Blumea Biodivers Evol Biogr Plants 48 (2): 261-277. DOI: 10.3767/000651903X674964.

Alejandro GJD. 2007. The current status of the Philippine Rubiaceae. Philipp J Syst Biol 1 (1): 47-60. DOI: 10.3860/pjsb.v1i1.908.

Alejandro GJD, Meve U, Uy M, Thiv M, Liede S. 2010. Molecular support of the classification of Greeniopsis Merr. in Aleisanthieae (Rubiaceae), with a revision of the genus. Taxon 59 (5): 1547-1564. DOI: $10.2307 / 20774048$.

Alejandro GJD, Meve U, Mouly A, Thiv M, Liede S. 2011. Molecular phylogeny and taxonomic revision of the Philippine endemic Villaria Rolfe (Rubiaceae). Plant Syst Evol 296 (1): 1-20. DOI: 10.1007/s00606-011-0472-9.

Alejandro GJD, Meve U. 2016. Rubovietnamia coronula sp.nov. Rubiaceae: Gardenieae) from the Philippines. Nord J Bot 34 (4): $385-$ 389. DOI: $10.1111 /$ njb.01020.

Alfeche NG, Alejandro GJD, Meve U, Liede S. 2020. Two new endemic species of Ophiorrhiza L. (Rubiaceae: Ophiorrhizeae) from Davao Oriental, Philippines. Nord J Bot 38 (3). DOI: 10.1111/njb.02581.

Amoroso VB, Aspiras RA, Polizon JJ. 2009. Participatory inventory and distribution of endangered, endemic and economically important plants in Hamiguitan range wildlife sanctuary, Davao Oriental. Blumea 54: 71-76. DOI: 10.3767/000651909X474113.

Aribal L, Fernando ES. 2014. Vascular Plants of the Peat Swamp Forest in Caimpugan, Agusan del Sur Province on Mindanao Island, Philippines. Asian J Biodivers 5 (1): 1-17. DOI: 10.7828/ajob.v5i1.478

Arriola AH, Alejandro GJD. 2015. A new species of Discospermum (Coffeeae, Rubiaceae) from Luzon, Philippines including its conservation status. Phtyotaxa 206 (1): 043-046. DOI: 10.11646/phytotaxa.206.1.7.

Arriola AH, Calaramo M, Alejandro GJD. 2015. Pyrostria triflora, a new species of Vanguerieae (Rubiaceae) from Luzon, Philippines.
Bangladesh J. Plant Taxon 22 (1): 55-58. DOI: 10.3329/bjpt.v22i1.23868.

Arriola AH, Paraguison L, Alejandro GJD. 2016. Kanapia (Vanguerieae): a new endemic genus of Philippine Rubiaceae. Plant Syst Evol 302 (7): 911-920. DOI: 10.1007/s00606 016-1307-5.

Aureo W, Reyes T, Mutia FC, Jose R, Sarnowski MB. 2020. Diversity and composition of plant species in the forest over limestone of Rajah Sikatuna Protected Landscape, Bohol, Philippines. Biodivers Data J 8: e55790. DOI: 10.3897/BDJ.8.e55790

Banag C, Manalastas N, Alejandro GJD. 2014. Synonymy of Philippine Ixora (Ixoreae, Rubiaceae) and Ixora silagoensis sp. nov. Nord J Bot 32 (6): 761-764. DOI: 10.1111/njb.00411.

Banag C, Thrippleton T, Alejandro GJD, Reineking B, Liede-Schumann S. 2015. Bioclimatic niches of selected endemic Ixora species on the Philippines: predicting habitat suitability due to climate change. Plant Ecol 216 (9): 1325-1340. DOI: 10.1007/s11258 015-0512-6.

Banag C, Mouly A, Alejandro GJD, Bremer B, Meve U, Grimm G, Liede Schumman S. 2017. Ixora (Rubiaceae) on the Philippines crossroad or cradle? BMC Evol Biol 17 (1): 131. DOI: 10.1186/s12862-0170974-3.

Batuyong MAB, Calaramo M, Alejandro GJD. 2021a. Diversity of Rubiaceae in Ilocos Norte, Northwestern Luzon, Philippines: A preliminary checklist, their distribution, and conservation status. Philipp J Sci 150 (SI): 487-502.

Batuyong MAB, Calaramo M, Alejandro GJD. 2021b. Rediscovery of Psychotria palimlimensis (Rubiaceae): a rare species found only in Ilocos Norte Philippines. Nord J Bot 39 (7). DOI: 10.1111/njb.03253.

Biag RD and Alejandro GJD. 2020.Rediscovery of Psychotria species, subspecies and varieties collected in the 1990s and new records of Antirhea benguetensis (Elmer) Valeton and Ixora longifolia Smith (Rubiaceae) in Northern Sierra Madre Natural Park, Luzon, Philippines. Biodiversitas 21 (10): 4524-4535. DOI: 10.13057/biodiv/d211059.

Biag RD and Alejandro GJD. 2021. Rubiaceae Flora of Northern Sierra Madre Natural Park, Isabela, Luzon, Philippines: Species Richness, Distribution and Conservation Status. Philipp J Sci 150 (3): 907-921.

Bremer B, Eriksson T. 2009. Time Tree of Rubiaceae Phylogeny and dating the family, subfamilies, and tribes. Intl J Plant Sci 170 (6): 766-793. DOI: $10.1086 / 599077$

Calaramo MA, Rubite RR, Pugal CM, Lin C. 2019. New Species of Begonia section Baryandra (Begoniaceae) from Northwestern Luzon, Philippines. Phytotaxa 407 (1): 36-42. DOI: 10.11646/ phytotaxa.407.1.6

Chavez JG, Meve U, Nurk NM, Liede-Schumann S. 2021. Disentangling Antirhea (Rubiaceae): resurrection of Guettardella and description of the new genus Achilleanthus. Bot $J$ Linn Soc. DOI: 10.1093/botlinnean/boab013.

CDFP. Pelser PB, Barcelona JF, Nickrent DL (eds) 2011. onwards. Co's Digital Flora of the Philippines. www.philippineplants.org

Davis A, Bridson D, Ruhsam M, Moat J, Brummit N. 2009. A global assessment of distribution, diversity, endemism, and taxonomic effort in the Rubiaceae. Ann Missouri Bot Gard 96 (1): 68-78. DOI: $10.3417 / 2006205$.

DENR Administrative Order. 2017. Updated national list of threatened Philippine plants and their categories. DAO 2017-11. https://server2.denr.gov.ph/uploads/rmdd/dao-2017-11.pdf.

DENR. Department of Environment and Natural Resources II. 2017. Northern Sierra Madre Natural Park Profile. Isabela, Luzon, Philippines.

de Guzman DQ, Nacua AE, Belgica TH, Clemente KJE, Alejandro GJD.2014. Assessment, Inventory and Ethnobotanical Survey of Medicinal Plants in Mount Malinao (Albay, Philippines). IJPTP 5 (3): 1014-1019.

Delprete PG, Jardim JG. 2012. Systematic, taxonomy and floristics of Brazilian Rubiaceae: an overview about the current status and future challenges. Rodriguesia 63 (1): 101-128. DOI: 10.1590/S217578602012000100009

Fernando ES, Co L, Lagunzad D, Gruezo W, Barcelona J, Madulid D, Lapis A, Texon G, Manila A, Zamura P. 2008. Threatened plants of the Philippines: a preliminary assessment. Asian J Biol Sci 3: 1-52.

Gordon EA, Franco OE, Tyrrell ML. 2005. Protecting Biodiversity: A Guide to CriteriaUsed by Global Conservation Organizations. For Environ Stud Publ 6: 1-160.

IUCN. 2019. The International Union for Conservation of Nature's Red List of Threatened Species. Version 2019-2. https://www.iucnredlist.org 
JSTOR. Journal Storage. 2000 onwards. Global Plants. https://plants.jstor.org/

Magtoto LM, Mones DG, Ballada KA, Austria CM, Dizon RM, Alangui WV, Reginaldo AA, Galvan WM, Dizon KT, Hetterscheid WLA 2013. Amorphophallus adamsensis (Araceae), a new species from Ilocos Norte, Philippines. Blumea 58 (3): 267-270. DOI: $10.3767 / 000651913$ X676673.

Malabrigo PL Jr., Tobias AB, Boncondin JC. 2018. Floristic composition, vegetation structure, and diversity pattern of Mt. Calavite Wildlife Sanctuary: Basis for management and conservation planning. Ecosyst Dev J 8 (2): 3-27.

Merrill E. 1923. Enumeration of Philippine Flowering Plants (Volumes IIV). Bureau of Printing, Manila. DOI: 10.5962/bhl.title.49412

Obico J, Alejandro GJD. 2013. A new species of Antherostele (Urophylleae, Rubioideae, Rubiaceae) from Mt. Sohoton, Samar, Philippines. Phytotaxa 104 (1): 53-57. DOI: 10.11646/phytotaxa. 104.1.8

Ong PS, Afuang KE, Rosell-Ambal RG. 2002. Philippine Biodiversity Conservation Priorities: A Second Iteration of the National Biodiversity Strategy and Action Plan. Department of Environment and Natural Resources, Conservation International Philippines, Biodiversity Conservation Program, University of the Philippines Center for Integrative and Development Studies, and Foundation for the Philippine Environment, Quezon City, Philippines.

Ordas JAD, Banag C, Alejandro GJD. 2017. Neonauclea viridiflora (Rubiaceae), a new species of Naucleeae from Eastern Samar, with notes on myrmecophytic species in the Philippines. Syst Bot 42 (2): 364-370. DOI: 10.1600/036364417X695592.

Ordas JAD, Pinarok NAA, Romeroso RB, Alejandro GJD, Banag CI 2019. A checklist of Rubiaceae species from Eastern Samar, Visayas, Philippines. Check List 15 (2): 295-312. DOI: 10.15560/15.2.295.
Ordas J, Razafimandimbison SG, Moran, CB, Alejandro, GJD. 2021. Phylogeny and the evolutionary origins of myrmecophytism in the Neonauclea clade (Rubiaceae) revisited, with particular emphasis on the Philippine lineages. Plant Syst Evol 307 (3): 1-11. DOI: 10.1007/s00606-021-01752-5.

POWO. 2021. Plants of the World Online. Facilitated by the Royal Botanic Gardens, Kew. http://www.plantsoftheworldonline.org/

Robbrecht E. 1988. Tropical woody Rubiaceae. Opera Botanica Belgica 1: $1-271$.

Rydin C, Razafimandimbison SG, Bremer B. 2008. Rare and enigmatic genera (Dunnia, Schizocolea, Colletoecema), sisters to species-rich clades: phylogeny and aspects of conservation biology in the coffee family. Mol Phylogenet Evol 48 (1): 74-83. DOI: 10.1016/j.ympev.2008.04.006.

Salamanes JDP, Chavez JG, Arriola AH, Alejandro GJD. 2015. A new species of Antirhea (Guettardeae, Rubiaceae) from Surigao del Norte, Philippines. Acta Bot Gallica Bot Lett 162 (3): 153-156. DOI: $10.1080 / 12538078.2015 .1062800$

Uy M, Alejandro GJD. 2012. Conservation status and nrITS-supported classification of the Philippine endemic genus Greeniopsis Merr. (Rubiaceae). Asia Life Sci 21 (2): 441-454.

Vallejo B. 2014. Biogeography of the Luzon Island, Philippines. The Entomological Society of Latvia.

Villanueva JC, Callanta RS Jr, Neptuno JA, Verin M, Bangcaya PS, Cabelin VL, Alejandro GJD. 2016. Molecular confirmation of the taxonomy of the Rubiaceous Mycetia apoensis (Elmer) Govaerts. Acta Manilana 64: 1-7.

WCSP. World Checklist of Selected Plant Families. 2021. World Checklist of Selected Plant Families (WCSP). Royal Botanic Gardens, Kew. https://wcsp.science.kew.org/cite.do 